\title{
Association between the Asp327Asn Polymorphism of Sex Hormone-Binding Globulin Gene and Prostate Cancer
}

\author{
Zahra Tahmasebi Fard ${ }^{1 *}$, Mandana Hasanzad ${ }^{2}$, Mohammad Reza Nowroozi ${ }^{3}$, Hanieh Zham ${ }^{4}$ \\ ${ }^{1}$ Department of cellular and Molecular Biology, Roudehen Branch, Islamic Azad University, Roudehen, Iran. \\ ${ }^{2}$ Medical Genomics Research Center, Tehran Medical Sciences Branch, Islamic Azad University, Tehran, Iran. \\ ${ }^{3}$ Uro Oncology Research Center, Tehran University of Medical Sciences, Tehran, Iran. \\ ${ }^{4}$ Department of pathology, Shohada Hospital, Shahid Beheshti University of Medical Sciences \& Cancer Research Center, Shahid Beheshti \\ University of Medical Sciences, Tehran, Iran.
}

Received: 12 May 2016

Revised : 4 Jun 2016

Accepted: 19 Jun 2016

Corresponding Author: Zahra Tahmasebi Fard Department of cellular and Molecular Biology, Roudehen Branch, Islamic Azad University, Roudehen, Iran Phone: +989122266686

E-mail: ztahmasebi@riau.ac.ir

\begin{abstract}
Background: By binding SHBG hormone to sex hormones, in addition to carrying them in the blood, they regulate the amount of tissue availability. The genetic changes in the structure of globulin affect its binding to hormones, so in this study the effects of single nucleotide change in exon 8 or rs 6259 in the incidence of prostate cancer was evaluated.

Materials and Methods: The study population included 120 patients with prostate cancer and 120 control subjects. After collecting blood samples, DNA was extracted by salting out procedure in order to determine the genotype of individuals by RFLP-PCR method. According to Hardy-Weinberg equilibrium genotypes the allele frequencies were calculated and a relationship between this variation and prostate cancer were evaluated using SPSS V.23.Also, the relationship between variations was investigated. P-values smaller than or equal to 0.05 were considered significant.

Results: Results indicated that homozygous mutant genotype AA 2.58 ( $\mathrm{p}$ value= 0.007, OR: 2.58, CI95\%: 1.52-4.38) and heterozygous AG increase the risk of prostate cancer in carriers by 1.18 times (p-value $=0.5$, OR: 1.18 , CI95\%: 0.38 3.61). But homozygous of wild genotype GG have a protective role against prostate cancer (p-value $=0.005$, OR: 0.385, CI95\%: 0.23-0.65).

Conclusion: Asn allele is one of the main factors in prostate cancer, therefore, it could be used as the non-invasive and suitable marker for early detection in susceptible individuals.
\end{abstract}

Keywords: Prostate cancer; Sex hormone-binding globulin; PCR-RFLP

Please cite this article as: Tahmesebi Fard Z, Hasanzad M, Nowroozi MR, Zham H. Association between the Asp327Asn Polymorphism of Sex Hormone-Binding Globulin Gene and Prostate Cancer. Res Mol Med. 2016; 4 (3): 29-34

\section{Introduction}

Prostate cancer is caused by malignancy and irregular proliferation of prostate cells. In most cases, it has slow growth and in some circumstances has fast growth (1). Evidence suggests that both environmental and genetic factors are involved in prostate cancer but complete understandings of the causes of prostate cancer are still unknown (2). The main risk factors for this cancer include smoking, poor diet, obesity, older age, family history, and genetic factors. Prostate cancer before 45 years of age is very unusual but its incidence increases by age (3).
Men who have first-degree relatives with prostate cancer are twice more at risk compared with men without a family history (4). Also, people with two first-degree relatives with prostate cancer are fivefold at risk of developing the disease (5).

Several studies have found a possible link between levels of androgens, such as testosterone and dihydrotestosterone circulating (DHT) and risk of prostate cancer in different ethnic groups (6). Androgens, which are male sex hormones are produced by the testes and adrenal glands and play a 
crucial role in male reproduction and sexual behavior (7). In addition to androgens which are essential for development, operation and maintenance of prostate, estrogen and female sex hormones also have roles in the male reproductive system through specific receptors of estrogen (8).

Sex hormone-binding globulin (SHBG) is a plasma glycoprotein that binds to active androgens and estrogens and carries them in the blood. The affinity of this protein for its ligand is about four to five times to albumin (9). Plasma SHBG is secreted by the liver (10), but SHBG gene mRNA have also been identified in a variety of hormone-responsive tissues including prostate (11), endometrium (12), fallopian tubes $(13,15)$, specifically in granulosa cells-lutein (14), and placenta (16). The local production of SHBG represents the regulation of access to steroids and activating signals, by autocrine and paracrine processes (10). SHBG gene is located on the short arm of chromosome $17 \mathrm{p} 12-13$ (17) with 8 exons, 7 introns, and $3.2 \mathrm{~kb}$ in length (18). The mature protein is a plasma homodimer which is made up of two identical or nearly equal monomers. Each monomer includes O-linked glycosylation site in the tyrosine amino acid 7 (Thy7) and two N-linked glycosylation sites at Asn351 and Asn367 positions (19).

Three polymorphisms have been reported in the protein-coding region of SHBG which leads to changes in its amino acid sequence. Genetic variants have different effects on protein. One of the changes is point mutations in exon 8 at the $\mathrm{N}$ - glycosylated site in which aspartic acid in position 327 is replaced by asparagine. Initial reports suggested that changes in glycosylation have no effect on steroid binding properties, but today it is recognized that in wild type, protein of carbohydrates is essential for correct attachment of glycoprotein to its receptor (20). The aim of this study was to investigate the relationship between polymorphism Asp 327 Asn (D327N) in exon 8 SHBG gene and risk of prostate cancer in Iranian population.

Table 1. Biochemical variables and clinical indicators in patient and control groups.

\begin{tabular}{|c|c|c|c|c|}
\hline \multirow{2}{*}{ Variable } & \multirow{2}{*}{ Range } & \multicolumn{2}{|c|}{ Mean \pm Std Error Difference } & \multirow{2}{*}{$P$ value } \\
\hline & & Case & Control & \\
\hline \multirow{4}{*}{ Age (years) } & $40-50$ & $18(15 \%)$ & $59(49.17 \%)$ & \multirow{4}{*}{0.000} \\
\hline & $50-60$ & $30(25 \%)$ & $42(35 \%)$ & \\
\hline & $60 \geq$ & $72(60 \%)$ & $19(15.83 \%)$ & \\
\hline & Mean \pm Std Error Difference & $67.88 \pm 0.77$ & $41.03 \pm 1.53$ & \\
\hline \multirow{3}{*}{ BMI $\left(\mathbf{k g} / \mathbf{m}^{2}\right)$} & $25 \geq$ & $59(49.17 \%)$ & $62(51.67 \%)$ & \multirow{3}{*}{0.398} \\
\hline & $25>$ & $61(50.83 \%)$ & $58(48.33 \%)$ & \\
\hline & Mean \pm Std Error Difference & $26.17 \pm 2.42$ & $25.08 \pm 2.05$ & \\
\hline PSA total $(\mathrm{nmol} / \mathrm{L})$ & Mean \pm Std Error Difference & $32.56 \pm 1.27$ & $15.72 \pm 2.06$ & 0.000 \\
\hline PSA Free(nmol/L) & Mean \pm Std Error Difference & $7.86 \pm 0.17$ & $1.92 \pm 2.16$ & 0.000 \\
\hline \multirow{3}{*}{ Smoker } & Never & 37 & 36 & \multirow{3}{*}{0.922} \\
\hline & Former & 49 & 52 & \\
\hline & Current & 34 & 32 & \\
\hline \multirow{4}{*}{ Stage of cancer } & Stage I & $71(42.5 \%)$ & & \\
\hline & Stage II & $42(35 \%)$ & & \\
\hline & Stage III & $15(12.50 \%)$ & & \\
\hline & Stage IV & $12(10 \%)$ & & \\
\hline
\end{tabular}

Materials and Methods

Study population

A case/control study was designed in which 120 Iranian men with primary prostate adenocarcinoma (patient group) attending Imam Khomeini Hospital (Research Center of The genitourinary) were recruited. They were selected based on physical examination, Digital Rectal Exam (DRE), serum levels of PSA, prostatic 
needle biopsy, histopathology report, and radical prostatectomy surgery. The same number of individuals were selected as control group who had no particular disease and also did not use any specific drug and had no acquired or genetic background of cancer, especially prostate cancer.

\section{Genotyping}

About 3 to $5 \mathrm{ml}$ blood were taken from all subjects that were mixed with EDTA, then frozen at $-20{ }^{\circ} \mathrm{C}$. DNA of all samples were extracted by salting out method and a spectrophotometer was used to determine the concentration of it. The polymorphism D327N forward primer with 5'- AGAAGAAGAT ATGGGGGCAGTG -3' sequences and reveres primer with 5'- GGGCCTGGTCCACATCC -3' sequence was used in order to amplify the fragment with $209 \mathrm{bp}$ length (20).

For every PCR reaction, $10 \mathrm{ml}$ of water and $10 \mathrm{ml}$ of the commercial master mix $2 \mathrm{X}$ amplicon (including Mgcl2 1.5mM, buffer, Taq enzyme, dNTP and other materials needed for reaction), 1 microliter of each primer and $100 \mathrm{ng}(1 \mu \mathrm{l})$ from genomic DNA of each patient were added and after mixing were placed in thermocycler (Eppendorf Master cycler gradient, Germany). Programs included $95{ }^{\circ} \mathrm{C}$ for 5 minutes, $95^{\circ} \mathrm{C}$ for 60 seconds, $62^{\circ} \mathrm{C}$ for 30 seconds, $75^{\circ} \mathrm{C}$ for 30 seconds at 37 cycles and $72{ }^{\circ} \mathrm{C}$ for 5 minutes in one cycle for amplification of $209 \mathrm{bp}$ of SHBG gene. The amplified products were electrophoresed on agarose gel $1.5 \%$ with DNA Safe beside $100 \mathrm{bp}$ size marker (Roche) at a constant voltage of 95 volts for 15 to $20 \mathrm{~min}$, till bands were seen.

Hinf I restriction enzyme was added to the amplified products containing $209 \mathrm{bp}$ band and incubated for 16 to 18 hours at $37{ }^{\circ} \mathrm{C}$. Then product of digestion enzyme was poured onto the $3 \%$ agarose gel. The amplified fragment contained two incision sites. First and second incision sites were located after 75 and 144 nucleotides from 5 ' end of the string. The first incision site in all the samples had been cut, but the second incision site which was a location of D327N polymorphism of SHBG gene, had cut just for unchanged samples for this position. In the presence of nucleotide $\mathrm{G}$ in the desired position, three bands namely 75bp, 69bp 64bp had appeared which indicated GG genotype. But if it changes to A only two bands namely $133 \mathrm{bp}$ and $75 \mathrm{bp}$ were seen, indicating that the genotype was AA. Heterozygous individuals possessed $133 \mathrm{bp}, 75 \mathrm{bp}, 69 \mathrm{bp}$, and 64bp bands.

\section{Ethics Statement}

This research was done in compliance with all norms and standards of the ethics committee (Islamic azad university of Tehran Medical Sciences Branch) and also by receiving written consent of the patients.

\section{Statistical Analysis}

Using genotype counts, their percentages and frequency were determined in cancer and control groups. The allele frequency in both groups was achieved according to Hardy-Weinberg equilibrium. The relationship between genotype and risk of prostate cancer in two groups were studied in SPSS ver. 23 applying Chi-square test.

\section{Results}

The body mass index (BMI) in 121 subjects was $\leq 25$ and in 119 it was more than 25. BMI in the two groups were not significantly different $(p=0.398)$. According to the pathology reports, 71 (42.5\%) patients were in Stage I, 42 in stage II (35\%), 15 in stage III $(12.5 \%)$, and 12 patients were in stage IV $(10 \%)$.

After ensuring the amplification of 209bp segment, the samples were exposed to Hinf I enzyme. Results of some digestion of the samples are shown in Fig. 1. To ensure the accuracy of genotypes determined, a number of samples were randomly selected and sequenced.

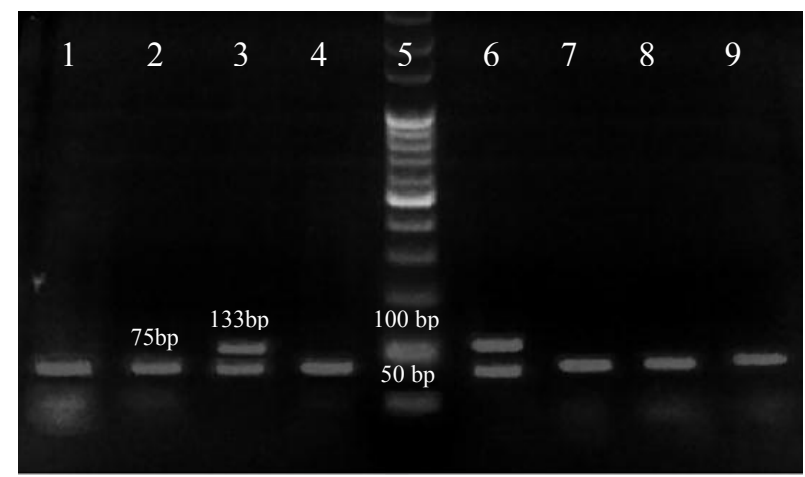

Figure 1. Results of the enzymatic digestion for some cancer and control samples: wells $1,2,4,7,8 \& 9$ is GG genotype, wells $3 \& 6$ is AA genotype, well 5 is marker $100 \mathrm{bp}$

\section{Results}

The results of the genotypes count are presented in Table 2. According to Hardy-Weinberg equilibrium, the frequency of allele $\mathrm{A}$ in the cancer group was 0.55 versus 0.33 in the control group. $G$ allele frequency in the cancer group and control group were 0.45 and 0.67 , respectively.

Statistically, a significant relationship was found between the two groups $(\mathrm{P}=0.007)$. By calculating the risk of prostate cancer, we found that individuals with AA genotype were 2.58 times, and people with AG / GA heterozygous genotype were 1.18 times more likely to develop prostate cancer. But GG homozygous genotype had a protective role against prostate cancer $($ odds Ratio $=0.385)$. 
Table 2. Statistical analysis of genotypes

\begin{tabular}{llllll}
\hline Genotype & Tumor group & Control group & P Value & Odds ratio & CI 95\% \\
\hline AA & $63(52.5 \%)$ & $36(30 \%)$ & 0.007 & 2.58 & $1.52-4.38$ \\
GG & $50(41.6 \%)$ & $78(65 \%)$ & 0.005 & 0.385 & $0.23-0.65$ \\
AG/GA & $7(5.8 \%)$ & $6(5 \%)$ & 0.5 & 1.18 & $0.38-3.61$ \\
\hline
\end{tabular}

\section{Discussion}

Prostate cancer is the main cause of cancer death in Iran (21). However, some studies have shown that unlike America and Europe, prostate cancer is not common in Iran (22). Accurate statistics are not available in Iran but in 2007 the incidence of this cancer in Iran was about 1.5 per 100,000 people in a year which was much lower compared to Western countries. In western countries, this rate is extremely high, from 50 to 500 cases per 100,000 people in a year. However, the number of males with prostate cancer is increasing compared to previous years, so it is highly important to prevent and control it for the health of the society (22). Prostate cancer is dependent on testosterone and androgen metabolism, so it seems reasonable to assume that genetic changes in active genes which are involved in hormones pathways can affect the risk of developing the disease (8). Since plasma glycoprotein SHBG is considered as a carrier protein for the active androgen and estrogen, genetic changes affect its plasma distribution and can change the access of target tissues cells (23).

The D327N polymorphism is a functional polymorphism that causes adding Glycosylation to $\mathrm{N}$ Linked into the C-terminal of laminin G-like globular domain protein (24). In animal models it was identified that additional carbohydrate chains in the protein SHBG (which codes by Asn 327 allele) reduced its metabolic clearance and increased the half-life of the protein. For this reason, an increase in SHBG serum levels for carriers of these alleles can be seen (25).

Testosterone controls how the prostate gland grows and develops. For patients with advanced or metastatic prostate cancer, hormone therapy with anti-androgen compounds might be the last best hope (26). Also, some found a strong relationship between SHBG gene polymorphism and risk of developing prostate cancer (27). But, there is no study about the detection of Rs 6259 polymorphism of SHBG in Iranian men and prostate cancer. We decided to evaluate the relationship between polymorphism of exon 8 SHBG and prostate cancer in order to diagnose the disease in early stages.

The rs6259 polymorphism in exon 8 SHBG occurs due to change of $\mathrm{G}$ nucleotide to A nucleotides. After analyzing the genotypes in two groups AA homozygous genotypes were found in 63 people $(52.5 \%)$ in cancer group and in $36(30 \%)$ of the control group ( $\mathrm{p}$-value $=0.007$ ). Also GG homozygous genotype included 50 people $(41.6 \%)$ in cancer group and $75(65 \%)$ in control group (p-value=0.005). Genotype AG / GA in cancer group and controls included $7(5.8 \%)$ and $6(5 \%)$ individuals, respectively $(\mathrm{p}$-value $=0.5)$. The frequency of $\mathrm{A}$ mutant allele in the cancer group was more than the control group while $\mathrm{G}$ allele was more frequent in the control group. The results of the present study were in line with those of Berndt \& et al in which polymorphisms in associated genes with hormones and risk of prostate cancer were investigated. rs 6259 Exon 8 was one of the polymorphisms examined among 14 polymorphisms. The study showed an association between rs 6259 Exon 8 and risk of developing prostate cancer, and it was found that genetic variation of SHBG could influence the susceptibility to prostate cancer (27).

A study was done to understand the molecular mechanism of hormone resistance and its association with disease progression in patients with prostate cancer and AR and SHBG gene polymorphisms were evaluated. Results showed that polymorphism 5790 $\mathrm{G}>\mathrm{A}$ (rs 6259) can be proposed as a good marker for patients with hormone resistance (28).

In another study, serum concentrations of total testosterone, estradiol, and ratio of testosterone to estradiol and also ratio of binding globulin SHBG to sex hormone which are associated with prostate cancer were evaluated in 631 healthy volunteers and the results led to the hypothesis that prostate tissue biology depends on the duration of exposure to sex steroids and is effective on people's lives (29).

The association between breast cancer and rs 6259 polymorphism was investigated by Cui Y (30), Piccioni (31), Dunning et al. (32). Similar to the current results, they found that this polymorphism might be involved in causing cancer. This polymorphism was also found to be associated with risk of type 2 diabetes and increase in SHBG serum levels by $10 \%$ (33).

The present study suggests that Rs 6259 polymorphism could be associated with the susceptibility of Prostate cancer. The odds ratio of the 
AA mutant genotype was calculated as 2.58 (p value $=0.007$, OR: 2.58 , CI95\%: 1.52-4.38), showing the significant effect of this genotype in causing the disease. It seems that SHBG gene polymorphisms like genetic changes could influence the development of prostate cancer. Inconsistent results may be due to differences in genetic studies in different populations or other changes such as different techniques applied for polymorphism identification. Further studies with larger sample sizes are recommended in order to assess the accuracy of these findings.

\section{Acknowledgments}

The authors are thankful to Research Assistant of Islamic Azad University, Roudehen Branch for financial supports. Also, we would like to express our gratitude to the medical personnel in Imam Khomeini Hospital, Tehran and all the patients who participated in this study. Special thanks go to Dr. Amini for introducing the patients.

\section{Authors' contributions}

TZ developed the study concept, designed the protocol, and wrote the manuscript. HM analyzed the data. NMR \& $\mathrm{ZhH}$ introduced patients for the research.

\section{Support/Funding}

This study was supported by Research Assistant of Islamic Azad University, Roudehen Branch

\section{Conflict of interest}

The authors have no conflicts of interest to declare.

\section{Role of sponsor}

The funding organizations are public institutions and had no role in the design and conduct of the study.

\section{References}

1. Boyle P, Levin B. WCR: IARC Press, International Agency for Research on Cancer; 2008.

2. Seydali Route M, Tahmasebi Fard Z. The Correlation between CYP450 Ile462Val Polymorphism and Prostate Cancer in a Group of Iranian Men. MEJC. 2016; 7(2): 79-84.

3. Ankerst DP, Tangen CM, Thompson IM. Prostate Cancer Screening: Medical. Second Edition. Humana press. 2009.

4. Kral M, Rosinskaa V, Studenta V, Grepla M, Hrabeca M, Bouchalb J. Genetic Determinants of Prostate Cancer: a review.

Biomed Pap Med Fac Univ Palacky Olomouc Czech Repub. 2011; 155(1):3-9. PMID: 21475371

5. Nemesure B, Wu SY, Hennis A, Leske M C. Family History of Prostate Cancer in a Black Population. J Immigr Minor Health. $2013 ; 15(6): 1-11$.

6. Carlson NR. Physiology of Behavior. 11th edition. Pearson Higher Ed. 2012. p. 326. ISBN 0205239390.
7. Ficarra, V, Novara G, Zattoni F. The role of the prostate cancer antigen 3 (PCA3) test for the diagnosis of prostate cancer in the era of opportunistic prostate-specific antigen screening. Eur Urol. 2010: 58(4); 482-4. PMID: 20685032

8. Thompson, Ian M, et al. Prevalence of prostate cancer among men with a prostate-specific antigen level $\leq 4.0 \mathrm{ng}$ per milliliter. NEJM. 2004: 350(22); 2239-46.

9. Hammond GL. Diverse roles for sex hormone-binding globulin in reproduction. Bio Rep. 2011: 85 (3); 431-41. PMID 21613632

10. Pugeat M, Nader N, Hogeveen K, Raverot G, Déchaud H, Grenot C. Sex hormone-binding globulin gene expression in the liver: drugs and the metabolic syndrome. Mol Cell Endocrinol. 2010; 316(1):53-9. PMID: 19786070

11. Nakhla AM, Hryb DJ, Rosner W, Romas NA, Xiang Zh, Kahn SM . Human sex hormone-binding globulin gene expressionmultiple promoters and complex alternative splicing. BMC Mol Biol. 2009; 10: 37. PMID: 19416531

12. Misao R, Itoh N, Mori H, Fujimoto J, Tamaya, T. Sex hormone-binding globulin mRNA levels in human uterine endometrium. Eur J Endocrinol. 1994: 131(6); 623-9. PMID: 7804446

13. Watson, Cheryl S. The Identities of Membrane Steroid Receptors: And Other Proteins. Science. 2012.

14. Forges T, Gerard A, Hess K, Monnier-Barbarino P, Gerard H. Expression of sex hormone-binding globulin (SHBG) in human granulosa-lutein cells. Mol Cell Endocrinol. 2004. 19(1-2); 61-8. PMID: 15149727

15. Chen Ch, Smothers JC, Lange A, Nestler JE, Strauss JF, Wickham EP. Sex Hormone-Binding Globulin Genetic Variation: Associations with Type 2 Diabetes Mellitus and Polycystic Ovary Syndrome. Minerva Endocrinol. 2010. 35(4): 271-80. PMID: 21178921

16. Sun L, Jin Z, Teng W, Chi X, Zhang Y, Ai W, et al. SHBG in GDM maternal serum, placental tissues and umbilical cord serum expression changes and its significance. Diabetes Res Clin Pract. 2013; 99 (2):168-73. PMID: 23164471

17. Nakhla AM, Hryb DJ, Rosner W, Romas NA, Xiang Z, Kahn SM. Human sex hormone-binding globulin gene expressionmultiple promoters and complex alternative splicing. BMC Mol Biol. 2009; 10: 37. PMID: 19416531.

18. Gershagen S, Lundwall A, Fernlund, P. Characterization of the human sex hormone binding globulin (SHBG) gene and demonstration of two transcripts in both liver and testis. Nucleic Acids Res, 1989: 17(22); 9245-58.

19. Rosner W, Hryb DJ, Khan MS, Nakhla AM, Romas NA. Sex hormone-binding globulin mediates steroid hormone signal transduction at the plasma membrane. J Steroid Biochem Mol Biol. 1999; 69(1-6):481-5. PMID:10419028

20. Haghighi N, Tahmasebi fard Z, Nafisi N. Investigation of Association between E326K in SHBG Gene and Breast Cancer in Iranian Females. J Fasa Univ Med Sci. 2015:5 (2); 289-95.

21. Moslemi MK, Lotfi F, Tahvildar SA. Evaluation of prostate cancer prevalence in Iranian male population with increased PSA level, a one center experience. Cancer Manag and Res. 2011; 3:227-32. 
22. Sadjadi A, Nooraie M, Ghorbani A, Alimohammadian M, Zahedi M-J, Darvish-Moghadam S, et al. The incidence of prostate cancer in Iran: results of a population-based cancer registry. Arch Iran Med. 2007; 10(4):481-5.

23. Svartberg J, Løchen ML, Schirmer H, Jorde R, Wilsgaard T, Mathiesen EB. Single-nucleotide polymorphism, rs1799941 in the Sex HormoneBinding Globulin (SHBG) gene, related to both serum testosterone and SHBG levels and the risk of myocardial infarction, type 2 diabetes, cancer and mortality in men. Andrology. 2014; 2: 212-18. PMID:24327369

24. Power SG, Bocchinfuso WP, Pallesen M, Warmels-Rodenhiser S, Van Baelen H, Hammond GL. Molecular analyses of a human sex hormone-binding globulin variant: evidence for an additional carbohydrate chain. J Clin Endocrinol Metab. 1992; 75:1066-70. PMID:1400872

25. Parwanto ME, Suweino S, Tjahjadi D, Senjaya H, Edy HJ, Pakpahan A. The effect of sex hormone-binding globulin (SHBG) protein polymorphism on the levels of SHBG, testosterone, and insulin in healthy Indonesian men. Int J Med Sci Public Health. 2016; 5(4): 799-806. doi: 10.5455/ijmsph.2016.17122015293

26. Joseph JD, Wittmann BM, Dwyer MA, Cui H, Dye DA, McDonnell DP, Norris JD. Inhibition of prostate cancer cell growth by second-site androgen receptor antagonists. Proc Natl Acad Sci U S A. 2009; 106(29): 12178-83. PMID: 19574450

27. Berndt SI, Chatterjee N, Huang WY, Chanock SJ, Welch R, Crawford ED, et al.: Variant in sex hormone-binding globu-lin gene and the risk of prostate cancer. Cancer Epidemiol Biomarkers Prev. 2007; 16: 165-8. PMID: 17220347
28. Monteiro C, Sousa MV, Ribeiro R, Maurício J, Fraga A, Medeiros R. Genetic variants in AR and SHBG and resistance to hormonal castration in prostate cancer. Med Oncol. 2013:30(1); 490 .

29. Salonia A, Abdollah F, Capitanio U, Suardi N, Gallina A, Castagna G, et al. Circulating sex steroids and prostate cancer: introducing the time-dependency theory. World J Urol. 2013: 31(2):267-73. PMID: 23283410

30. Cui Y, Shu XO, Cai Q, Jin F, Cheng JR, Cai H, et al. Association of breast cancer risk with a common functional polymorphism (Asp327Asn) in the sex hormone-binding globulin gene. Cancer Epidemiol Biomarkers Prev. 2005:14(5); 1096101.PMID: 15894658

31. Piccioni C, Graziella Catalano M, Boccuzzi G, Fortunati N. Sex hormone-binding globulin (SHBG) gene pentanucleotide TAAAA repeat and $\mathrm{D} 327 \mathrm{~N}$ polymorphism in breast cancer: link to estrogen sensitivity Endocrine Abstracts. 2010: 22; 390-7.

32- Dunning AM, Dowsett M, Healey CS, Tee L, Luben RN, Folkerd E, et al. Polymorphisms Associated With Circulating Sex Hormone Levels in Postmenopausal Women. JNCI J Natl Cancer Inst. 2004: 96 (12); 936-45. PMID:15199113

33. Ding EL, Song Y, Manson JE, Hunter DJ, Lee CC, Rifai N, et al. Sex hormone-binding globulin and risk of type 2 diabetes in women and men. N Engl J Med. 2009:361(12):1152-63. PMID: 19657112 